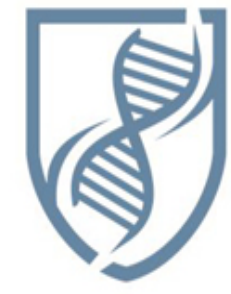

Journal of Bioscience and Applied Research

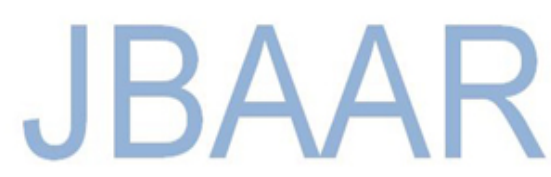

WWW.JBAAR.ORG

\title{
Molecular and cytochemical comparative assessment between the two food additives,sunset yellow and curcumin-induce testicular toxicity in mice
}

\author{
Mohamed A. Ismail \\ Department of Biological Sciences, Faculty of Education, Ain Shams University, Cairo, Egypt \\ (Corresponding author-e mail: $\underline{\text { mohesmael@hotmail.com) }}$
}

\begin{abstract}
The present work was planned to study the effects of E110 (sunset yellow) as a common synthetic in Egypt and E110 (curcumin) as a natural food-drug colorants on the testis of the male mouse. The plan of work was designed to cover six parameters: histopathological, cytochemical (involving DNA and total proteins), testis weight, sperm parameters (i.e., sperm abnormalities and sperm motility), and measuring testosterone levels in blood sera. The mice were divided into three groups, ten per each. The first group remained as controls, whilst the second orally given sunset yellow-E110 (30 mg/kg b.wt/day) as SY-group and the third one E100 'CU-group' also gavage $37 \mathrm{mg} / \mathrm{kg}$ b.wt., both fed on their acceptable daily intake (ADI) dosages for 60 days. The results detected that SY revealed distinct alterations in the desired parameters, particularly histological changes in structure of seminiferous tubules such as vacuolation, necrosis and multinucleate cells. Whilst, the cytochemical DNA and proteinic profiles of the SY-treatment mice exhibited severe damage in the DNA and total protein configurations. However, such deteriorations in the spermatogenic epithelia were also approved with changes in the other criteria after administration with E110. From such alterations, the E110 recorded a highly significant increase $(P<0.0001)$ in the abnormalities of sperm morphology and motility. Moreover, the testosterone levels in sera of male mice indicated the significant differences among groups. The molecular protocol manifested SY (E110) - induced DNA polymorphic changes in confrontation with control by primer OPC07, whilst CU (E100) kept on the control pattern. In conclusion, the present study explored the possibility of using the applied six parameters to

assessment and differentiate between the two food flavours indicating that E100 (CU) is more biosafe than the synthetic additive E110 (SY).

Keywords: Testis, Sunset yellow, Curcumin, DNA, Proteins, testosterone

\section{Introduction}

The food additives (i.e., food colouring agents) are any substance intentionally added to the foods for modifying their chemical, biological, sensorial, or physical characteristics without a nutritional purpose, and also to influence the consumer perceptions of the food 's flavor and quality (Gomes et al., 2013; Abbey et al., 2014). Food colours are classified as natural and synthetic agents (Harris, 1986; Abbey et al., 2014). The synthetic food colours (such as sunset yellow "SY") are added to foods to replace natural colour lost during processing, to reduce batch-to-batch variation and to yield products with consumer appeal where no natural colour exists (Tripathi et al., 2007).

Sunset yellow (SY) is an Azo dye authorized as a food additive. It is the most synthetic food dye which is prevalent in soft drinks and it was detected in beverages and liquor for adult (Ha et al., 2013; Li et al., 2013). SY was also found in chocolate for infants and children (Ha et al., 2013; Botelho et al., 2014). Moreover, SY was detected at high concentrations in cookies, ice cream, fruit juice, sauces, saffron, seasonings, relishes, pickles, chuntney and coloured rice besides sugar- and gelatin-based confectionery (Hajimahmoodi et al., 2013; Wu et al., 2013; Andrade et al., 2014; Shen et al., 2014; Vasques et al., 2014; Wang et al., 2014). Rajamanickam et al (2015)
\end{abstract}


reported that the kinetics of SY Azo dye photodegradation was detected under natural sunlight illumination by inducing photocatalytic application.

The adverse effects of the synthetic food colouring agents such as SY were also experimentally investigated in animal models by different researchers such as Abou ELZahab et al. (1997) who mentioned that administration of SY for 60 days into rats induced damage to liver tissue. Also, Hashem et al. (2011) indicated that the food colouring "amaranth and SY" at dosage of $47 \mathrm{mg} / \mathrm{kg}$ b.wt. in rats could impair hepatic function and should be avoided during pregnancy. Furthermore, Sayed et al. (2012) verified the mutagenic action of SY dye at dosage of $0.325 \mathrm{mg} / \mathrm{kg}$ b.wt./day for 1,2 or 3 weeks alone or with selenium and $\mathrm{A}$, $\mathrm{C}$ and $\mathrm{E}$ vitamins in mice with significant chromosomal aberration values in the liver and germinative cells. Ismail and Sakr (2016) reported drastic ultrastructural effects in the hepatocytes, chromosomal aberrations and the frequency of Mitotic Index (MI) of bone marrow cells at a highly significant increase $(p<0.0001)$.

Curcumin (CU) is a polyphenol derived from the turmeric rhizomes of the plant (Curcuma longa) (Duvoix et al., 2005), it offers hope for the development of a safe alternative crucial natural food colourant instead of the synthetic food dye "SY".

Curcumin is used as a spice to give specific flavor and yellow color to Curry (Pari et al., 2008). It was found to exhibit various promising biological activities including anti-inflammatory (Rao et al., 1982; Satoskar et al., 1986), anti-platelet (Srivastava et al., 1986), antimutagenic (Nagabhushan et al., 1987), anti-HIV (Jordan and Drew, 1996), antioxidant (Masuda et al., 1999), anticancer (Chan, 1995; Singh and Aggarwal, 1995) and cancer chemopreventive (Mariadason et al., 2000). In 2015, Franceschi et al. revealed that in Western countries, CU as a herbal medicine, dietary supplement and bioactive nutraceutical is becoming more popular for improving the quality of life of neurological patients by treating aging and memory loss. Eigner and Sholz (1999) reported that safety dietary consumption of turmeric CU up to $1.5 \mathrm{~g}$ per person a day was not associated with adverse effects in humans. In extremely support, Cheng et al. (2001) verified that high dose of oral CU up to $8 \mathrm{~g}$ daily for 3 months to patients with pre-invasive malignant or high risk pre-malignant conditions, stating that no toxicity was observed. Furthermore, in patients with advanced colorectal cancer treated with CU, it was well tolerated at all dose levels up to $3.6 \mathrm{~g}$ daily for up to 4 months (Sharma et al., 2004).

Therefore, the present study was undertaken to compare between the synthetic sunset yellow (E110) and natural curcumin (E100) to find the alternative biosafe nutraceutical food additive by assessment both dyes as their impacts on the testes of male albino mice.

\section{Materials and Methods \\ Experimental Animals}

\section{2-1-The Experimental animals}

Thirty adult male Swiss albino mice (Mus musculus) with weights ranged between 24 and $26 \mathrm{~g}$ were used in this study. They were obtained from the animal house of
Theodor Bilharz Research Institute, Giza, Egypt. Mice were housed in clear plastic cages with wood chips as bedding in a room with a temperature of $25 \pm 2^{\circ} \mathrm{C}$, a relative humidity of $55 \pm 5 \%$ and a 12-h light/dark cycle during the period of the experiment. They were feed with standard laboratory rodent pellets and water ad-libitum. The animals were acclimatized for a period of one week prior to commencement of the experiment. All experimental procedures were done taking into consideration the ethical and scientific protocols recommended by Ferdowsian and Beck (2011).

\section{2-2-The Applied Chemicals and Dosages}

Two food additives were used in the current study; the synthetic colorant supplement "sunset yellow" and the natural yellow colorant "curcumin". The synthetic food colourant "sunset yellow" (Code No.: E110) as stated by NTP (1981); Hajimahmoodi et al. (2013). Whilst, the natural food colorant "curcumin" powder (Code No.: E100) was derived from the turmeric rhizomes (Curcuma longa) (Duvoix et al., 2005).

According to Reagan-Shaw et al. (2008), to convert the dosages of the acceptable daily intakes (ADI) of both sunset yellow (JECFA, 1982; SCF, 1984) and curcumin (JECFA, 2004; EFSA, 2010) from human to mouse, were calculating $30 \mathrm{mg} / \mathrm{kg}$ b.wt./day for sunset yellow and 37 $\mathrm{mg} / \mathrm{kg}$ b.wt./day for curcumin.

\section{2-3-Experimental Design}

The mice were divided randomly into three groups of ten animals each as follows:

Group I (Control group): Mice were orally feeding with $1 \mathrm{ml} / 25 \mathrm{~g}$ b.wt./day drink water by gastric tube for 60 days parallel to the treated groups.

Group II (SY-group): Animals were orally given sunset yellow-E110 (30 mg/kg b.wt/day) dissolved in drink water $(1 \mathrm{ml} / 25 \mathrm{~g}$ b.wt./daily) by feeding tube for 60 days.

Group III (CU-group): Mice were orally feeding with curcumin-E100 (37 mg/kg b.wt.) suspended in drink water (1 ml /25 g b.wt./daily) for 60 days.

At the end of the experiment, both control and treated mice were fasted overnight and then anaesthetized under light ether anesthesia. They were dissected and their testes were rapidly excised and weigh, and processed for histological, cytochemical, sperm parameters and molecular preparations. The sera of withdrawal heart blood is used in measuring of testosterone.

\section{2-4-Histological Preparations}

Male mice were killed after cervical dislocation. Testes were removed and. To prevent the loss of secretory fluid, the base of each seminal vesicle was grasped with forceps before removing. The testes fixed rapidly in aqueous Bouin`s fixative for 24 hours. Then, they were subjected to the normal steps for paraffin sectioning. $4 \mu \mathrm{m}$ serial testes 
sections were stained with haematoxylin and eosin (H\&E), dehydrated, cleared in xylene and mounted in DPX (Bancroft and Gamble 2002). The histological sections were examined and photographed with light microscopy.

\section{2-5- Cytochemical Preparations}

To exhibit DNA inclusions alone, Feulgen nuclear reaction was applied to exhibit the cytochemical DNA in testis specimens fixed in Carnoy's fluid as recommended by Darlington and Cour (1969); Kasten (2003). Paraffin sections were subjected to mild hydrolysis in $\mathrm{N}-\mathrm{HCl}$ at $60^{\circ} \mathrm{C}$, then treated with Schiff's reagent. Consequently DNA-containing particles acquired a purple or magenta colouration. Some sections were counter - stained with dilute aqueous solution of $1 \%$ light green, followed by a rapid washing in absolute alcohol. DNA inclusions were also showed degrees of purple stainability, as verified by deoxyribonuclease enzyme while the ground cytoplasm took a greenish colouration.

The total proteins were displayed in the present specimens by using the mercury bromophenol blue method of Mazia et al. (1953), using Bouin's or Carnoy's fixative. The stained sections were also mounted in DPX. Consequently, the existence of proteins was generally indicated by the development of bluish stainability.

\section{2-6-Mouse sperm collection for scoring the abnormalities}

This method of extraction is used for acrosome reaction assay according to Jungnickel et al. (2001); Takeda et al. (2016), by collecting two cauda epididymis from one male, cut them 5 times and place them in a $2.0 \mathrm{ml}$ Eppendorf tube with $500 \mu \mathrm{l}$ of warm Whittens-HEPES media ( $\mathrm{pH} 7.2-7.4$ ), then incubate them at $37 \mathrm{C}$ for $10-15$ min to allow sperm to swim out and then photographed at magnification X1000 by using a negative phase-contrast microscope. The sperm abnormalities were recorded in 1000 sperm/ each set ${ }^{\mathrm{n}=5}$. Furthermore, the Feulgen technique was also applied to investigate the sperm head abnormalities in the testes sections, then photographed.

\section{2-7-Analysis of sperm motility}

According to Takeda et al. (2016), sperm motility was evaluated immediately by placing a $10-\mu \mathrm{L}$ drop of diluted sperm suspension between a glass slide and a cover slip and counting the sperm under a phase-contrast microscope at $\times 1000$ magnification. Sperm motility was assessed as the \% motile cells for clear 1000 sperm. Estimate the sperm motility rate in the three groups (C-, SY- \& CU-groups) of that investigation, 1000 sperm for each $^{\mathrm{n}=5}$.

\section{2-8-Testosterone Analysis}

The animals were dissected 24 hours after the last treatment. Blood was taken from the hearts of the animals and preserved at $37^{\circ} \mathrm{C}$ for 30 minutes, then centrifuged $(1000 \mathrm{~g})$ for 15 minutes. The collected blood was centrifuged at $25^{\circ} \mathrm{C}$ and $4000 \mathrm{rpm}$ for 10 minutes in order to obtain the serum. The serum samples were kept frozen at $-18^{\circ} \mathrm{C}$. The blood testosterone level was analyzed by enzyme linked immunosorbent assay (Testosterone rat/mouse ELISA, MyBioSource's Products, MBS494055, Argentina).

\section{2-9-Molecular protocol}

According to Maniatis et al. (1982) and Ausubel et al. (1989) with modifications by Kumar et al. (2016), the extraction of genomic DNA from testes of mice for the three groups (control, SY- and CU-treated animals) was applied. The DNA pellet was carefully dried in laminar airflow. The dried DNA was dissolved in minimum amount of TE buffer ( $\mathrm{pH}$ 8.0). The quantity of total DNA isolated was checked by adding $2 \mu \mathrm{l} 6 \times$ orange loading dye (Fermentas, USA) to $2 \mu \mathrm{l}$ of isolated DNA. Four micro liters of this isolate was loaded in a well of $0.8 \% \mathrm{w} / \mathrm{v}$ agarose gel containing $0.05 \%$ of ethidium bromide.

Random Amplified Polymorphic DNAPolymerase Chain Reaction (RAPD-PCR) for genomic DNA was employed to detect any polymorphic changes in the genomic DNA of experimental animals compared with controls. RAPD-PCR was performed on the DNA of testicular mice cells of SY- and CU-orally fed for 60 days in comparison with their control DNA, as described by Zhou et al. (2013). Each experiment was repeated 3 or 4 times to be sure. Appropriate DNA marker of $\varphi$ X174 DNAHaeIII Digest visualized by ethidium bromide staining (Boehringer Mannheim GmbH, W. Germany) was loaded in an adjacent well. This investigation selected a primer OPC07 (5'-ATTCTGGTTT-3') as recommended by Zhou et al. (2013) to generate fingerprint polymorphisms among designed groups. These formed DNA bands of such selected primer OPC07 are related to the exons in hMSH2, ERCC1, XRCC1, and hOGG1 in tumorigenic cells (Zhou et al., 2013).

Data analysis for the dissimilarity coefficient and commonality percentages between all experimental cases and their controls were calculated based on pair wise comparison between them for a particular primer. For comparing the similarity between E110 (SY-treatment) and E100 (CU-treatment) in respective to their control mice. Polymorphic information content values were calculated for each OPC07 primer according to the formula of Jaccard's similarity Coefficient $(J)=a /(a+b+c)$, where $a=$ No. of presence of shared bands in both samples; $b=$ No. of bands present only in sample $1 ; c=$ No. of bands present only in sample 2. Clear and major RAPD-PCR bands were scored as presence-absence matrix (Collard and Mackill, 2009). This index can be modified to a coefficient of dissimilarity by taking its inverse: Jaccard's dissimilarity coefficient $=1$ $\mathrm{S}_{j}$ (where: $\mathrm{S}_{j}=$ Jaccard's similarity coefficient) (Kumar et al., 2016).

\section{2-10-Statistical Analysis}

Statistical analysis of the data of sperm parameters (sperm abnormalities and sperm motility) and testis weight, and determination of testosterone, was carried out by $t$-test, SPSS statistics 17.0 . Whereas, $p$-value $(p<0.05)$ was considered as a statistically significant, whilst $p$ value $(p<0.0001)$ was represented as a highly statistically significant. 


\section{Results}

\subsection{Histological observations}

\subsubsection{Group-I: The control mice}

The testis of control adult mouse is enveloped with a dense fibrous connective tissue capsule; the tunica albuginea, followed by loose connective tissue. The functional and the structural components of the testis comprise the seminiferous tubules and the interstitial tissue (Fig. 1). Each tubule contains spermatogenic stages resting on a basement membrane, the spermatogenic cells include the successive stages of spermatogenesis i.e. spermatogonia, primary spermatocytes, secondary spermatocytes, spermatids and spermatozoa (Fig. 2), in addition to Sertoli cells (Fig. 2). The seminiferous tubules are formed of several germinal epithelial layers surrounding a central lumen and covered with a thin basement membrane limited externally by peritubular or boundary tissue consisting mainly of elongated flat cells of fibroblasts and myoid cells, as illustrated in figure 2. The interstitial tissue is located between the seminiferous tubules. It consists mainly of loose fibrous connective tissue rich in blood vessels and capillaries, in addition to clusters of Leydig cells (Fig. 2).

\subsubsection{Group-II: The SY-treated mice}

The histopathological examination of cross sections of the testes of mice fed on SY for 60 days showed some alterations in both the seminiferous tubules and interstitial tissue (Figs. 4-8). The action of used food colourant SY resulted in a conspicuous disorganization of the germinal epithelia and disturbance of the general architecture of the seminiferous tubules (Figs. 4\&5). In which, some seminiferous tubules appeared exfoliated to their basement membranes (Fig. 4) and the lumens of others tubules occupying with banished cells mostly in early stages of spermatids and few malformed spermatozoa (Figs. 4\&5). Some spermatocytes and spermatids disposed from their original positions in successive stages of spermatogenesis at periphery of the seminiferous tubules to migrate towards the lumens as multinucleate giant cells (Fig. 6\&7), karyorrhexis or pyknosis of necrotic nuclei (Fig. 8). The affected spermatogonia and spermatocytes suffered from signs of degenerative changes accompanied with the presence of clear vacuoles in their cytoplasm, and their nuclei were darkly stained and visualized in pyknotic remnant cells, besides markedly azoospermia, as demonstrated in figures 6-8. A moderate changes were encountered in the interstitial tissue with approximately intact appearance, as evidenced in the specimen in figures 4-8.

\subsubsection{Group-III: The CU-treated mice}

Investigation of the effect of the nutraceutical 'CU' on the testes of mice displayed a normal configuration of plentiful number of spermatogenic successive stages in the seminiferous tubules, reflecting the negative effect of curcumin on the mice testes (Fig.8).

\section{3-2- Cytochemical Findings}

\section{3-2-1-DNA Feulgen technique}

Microscopic examination of the middle sections of the testis of control adult mice has shown that it is comprising the rounded or oval-shaped seminiferous tubules, which are occupied with waves of germinal epithelial and Sertoli cell nuclei in different degrees of Feulgen reactivity ranging from pink to magenta colour of DNA inclusions (Fig.10). Besides, the figure 10 displays that the areas lying between such seminiferous tubules are occupied by the interstitial tissue, which consists essentially of nuclear clumps of interstitial "Leydig" cells usually associated with blood capillaries of various sizes which are lined with endotheliallining cells with fusiform nuclei in a rather strongly staining of Feulgen reactivity. The spermatogonia nuclei are found in plentiful number in one or two layers marked by their more rounded nuclei with DNA contents of heterochromatin occupying all the nucleoplasm, as noted in the same above figure. Next to the spermatogonia, are the primary spermatocytes. The nuclei of such cells represent the largest nuclei of the whole spermatogenic lineage and are usually arranged in two or three layers. They exhibiting variable shapes and stainability degrees of DNA distribution depending on the phase of meiotic division (Fig. 10). The secondary spermatocytes are seen quite infrequently since they are difficult to observe in sections of mouse testis owing to the fact that their life span is short because they remain briefly in the interphase and soon enter into the second meiotic division producing the spermatids. The spermatid nuclei are appeared in figure (10) lying close to the lumina of the seminiferous tubules exhibiting marked variation in their shapes with the different degrees of elongation of their rounded-shaped nuclei during spermiogenesis process. Regarding the other type of seminiferous epithelial cells namely the "sustained nutritive or nurse (Sertoli) cells", which their nuclei are seen in figure (10) resting by their bases on peripheries of tubules and directed toward the lumina of the seminiferous tubules. The nuclei of Sertoli cells are comparatively large in size having oval or pyramidal shape, in moderately DNA contents. The nuclei of interstitial "Leydig" cells appeared oval shaped in a considerable moderately staining of dispersed DNA inclusions taking more condensation (figure 10).

With the period (60 days) of SY (E110) action at the level dose of ( $0.30 \mathrm{mg} / \mathrm{kg}$ b.wt.), striking deterioration was observed in the testicular tissue comparable to those examined in control (Fig. 11). The most evident changes in such instances represented with the distortion of testicular configuration in the pattern of DNA stainability, together with the seminiferous tubules became noticeably atrophied involving marked loss of the spermatogenic elements, whilst the remaining ones containing deformed strongly condensed DNA contents (figure 11). The nuclear DNA contents of Leydig cells appeared suffering from an obvious acute reduction of their Feulgen reactivity in all investigated sections under such treatment, as showed in figure 11. Spermatogenesis showed a marked arrest at the primary spermatocyte nuclei and most of the tubules were devoid of the advanced stages of spermatogenesis nuclei including the spermatids and sperms (Fig. 11). The great majority of primary spermatocyte nuclei revealed a marked increase in their number accompanied with a loss of their 

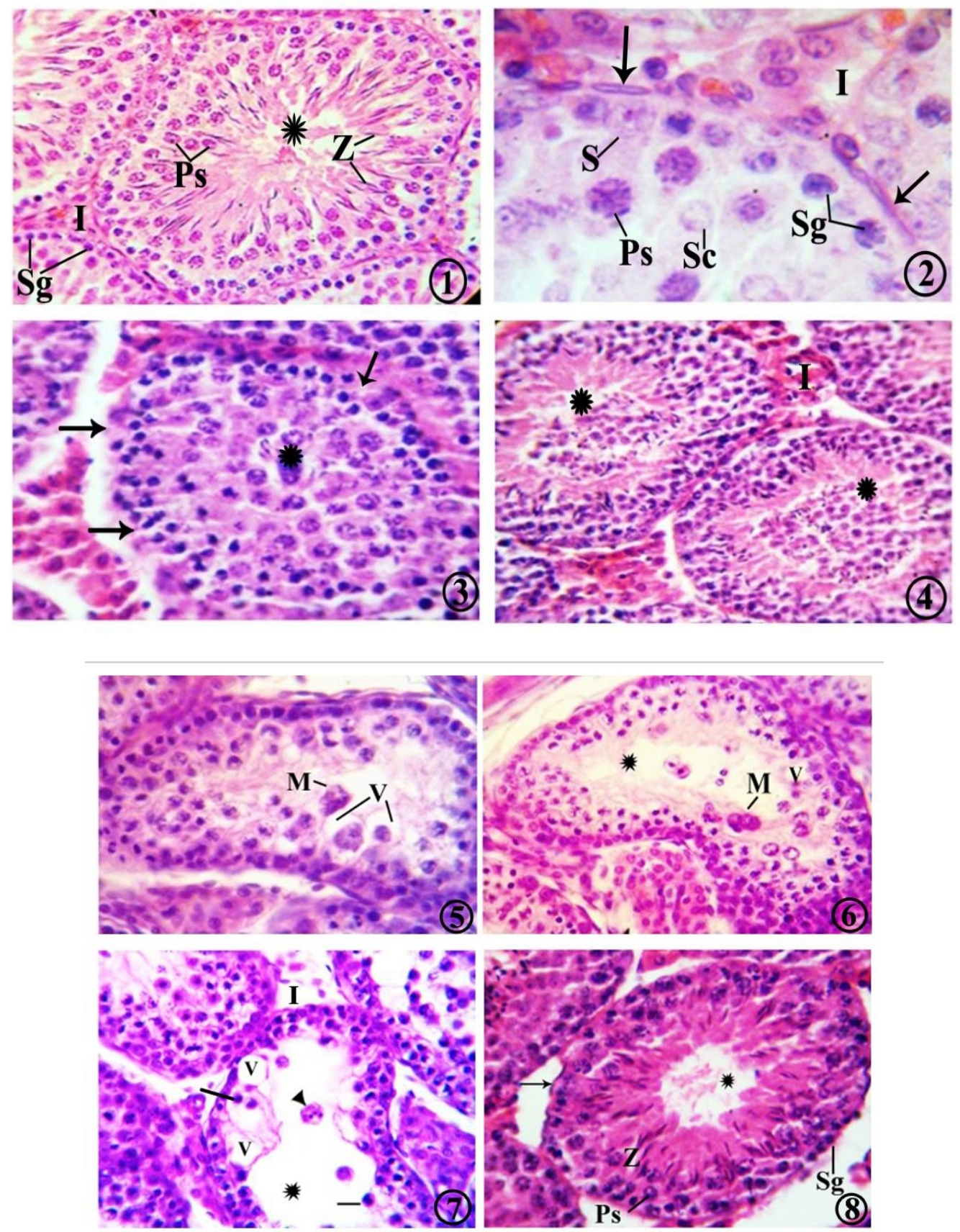

Figs. (1-8): Photomicrographs showing seminiferous tubules of testes sections stained with Hx.\& Eosin to show the spermatogenic stages, Sertoli, and Leydig cells in control (Figs. 2\&3), SY- (Figs. 3-7) and CU- (Fig. 8) groups.

Figs. (1\&2): Showing successive stages of spermatogenesis of control testes involving: spermatogonia (Sg), primary spermatocytes (Ps), secondary spermatocytes (Sc), different stages of spermatids and spermatozoa (Z) in the central lumina (*). Notice Sertoli cells (S) are resting by their triangular bases to the basement membrane, which formed of boundary tissue with elongated fibrocytes and myoid cells (arrows). The sections also reveal clumps of interstitial tissue (I) lying close to blood capillaries between the seminiferous tubules. (Fig. 1; X400 \& Fig. 2; X650)

Figs. (3-7): Photomicrographs of the testes of mice treated with E110 (SY-group) exhibiting disorganization of the germinal epithelia and disturbance of the general architecture of the seminiferous tubules. Some of them appeared exfoliated to their basement membranes (Fig. 3; arrows) and the lumens $\left(^{*}\right)$ of tubules occupying with sloughedbanished cells (Figs. 3\&4) and others seem to clear $(*)$. Figures 5 and 6 reveal the replacement of some spermatogenic stages with multinucleate giant cells (M) or became degenerative vacuoles (V). Fig. (7): Showing necrotic casts of spermatocytes in karyorrhexis (arrow head) or pyknosis (line) cases. (X400)

Fig. (8): Photomicrograph of the testis of mouse treated with E100 (CU-group) illustrating a normal configuration of spermatogenic successive stages in the seminiferous tubule. (X400) 


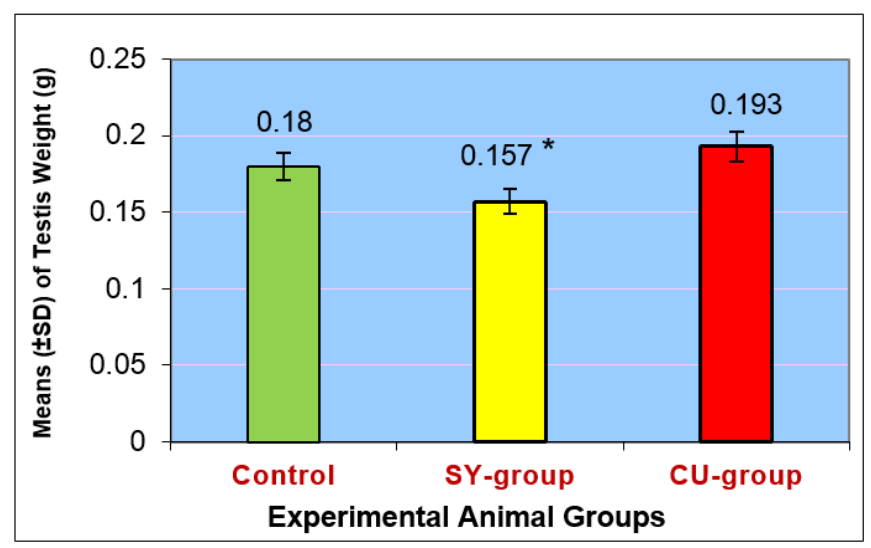

Fig. 9: Histogram of means $( \pm S D)^{\mathrm{n}=8}$ of testes weights in male mice after oral feeding with an equivalent ADI dose of either $30 \mathrm{mg}$ or $37 \mathrm{mg} / \mathrm{kg}$ b.wt./ daily, for 60 days in both SY - or CU-group respectively, and their respective control group, whereas each weighs at the end of feeding period. The significant differences among the groups showing a significant decrease $\left(\downarrow^{*} P<0.05\right)$ in testis weight after treatment with E110 (SY-group), and a non-significant increase ( $\uparrow P>0.05)$ in the set of E100 (CU-group).
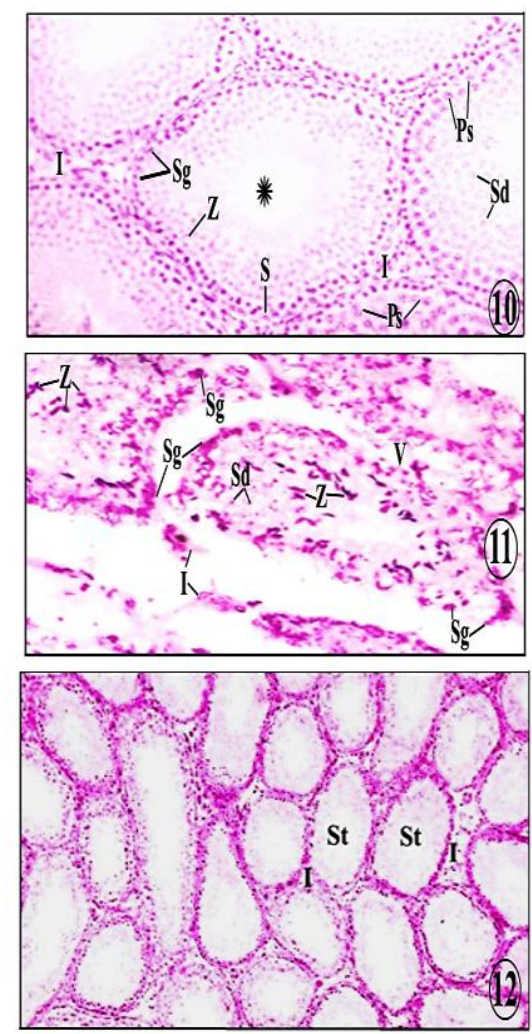

Fig. 10: Magnified seminiferous tubules of control adult mouse testis displaying the different degree of DNA stainability in the nuclei of spermatogenic cells including spermatogonia (Sg) taking a highest staining, primary spermatocytes (Ps) and spermatozoa (Z) have a moderate staining, whilst spermatids (Sd) reflect a lowest staining. Notice that the nuclei of interstitial "Leydig" cells (I) are clumped in between the tubules with a rather condensed staining. (Feulgen reaction $\mathrm{X} 400$ )

Fig. 11: Magnified atrophied seminiferous tubules of E110 (SY-group)-fed mouse testis exhibiting the adhesive aggregations of the nuclear DNA in both spermatogonia (Sg) and spermatozoa (Z) with an excessive strongly Feulgen reactivity. But the nuclei of primary spermatocytes and spermatids (Sd) appear losing their DNA contents with deteriorated meiotic figures with karyorrhexis appearance of DNA particles. Leydig" cell (I) nuclei reveal hypoplasia with vacuolation (V) and variation in their DNA stain affinity between each others. (X400)

Fig. 12: A magnified section of E100 (CU-group)- treated adult mouse testis showing regular normal configurations of compact round- or oval-shaped seminiferous tubules (St) having the waves of varied DNA stainability in the nuclei of spermatogenic cells and clumps of interstitial cell nuclei (I) between them. (X100) 
highly DNA stainability together with their meiotic figures. On the other hand, they exhibited highly DNA stainability, as manifested in figure 11 . The same previous figure showed a distinct reduction in the number of spermatogonia nuclei and when they found they reflected a highly condensed DNA stainability of pyknotic appearance. On the contrary, the treatment with E100 (CU-group) indicated that the configuration and distribution of DNA contents in the different stages of spermatogenesis, Sertoli and Leydig nuclei are distinctly appeared in a regular normal manner (Fig. 13).

\section{3-2-2-Total proteins}

The total proteins in the testes of adult control mice appeared, in general, as a strong bluish staining by using mercuric bromophenol blue technique, as represented by figures 13 . In the seminiferous tubules of such material, the total proteins were manifested as fine granules scattered at a random manner in cytoplasm and nuclei of both germ and Sertoli cells (Figs. 13). Moreover, the boundary tissue of the seminiferous tubules exhibited a highly bluish staining, indicating the richness of its fibers with the protein contents, as marked in figure (13). The nucleoproteins of spermatogonia gave an intensely bluish colouration of condensed proteinic clumps, as visualized in figure 13 . Furthermore, the chromatinic proteins of primary spermatocytes were investigated in variable states of their proteinic contents, whereas they appear in the different meiotic figures, as illustrated in figure (13). However, in general, such cells had a considerable deeply staining of protein inclusions. Sertoli cells manifested in a rather moderate stainability both in their radiated cytoplasm and nucleoproteins, which involved two intensely stained nucleoli in a darkly bluish colouration. The interstitial cells appeared deeply stained, indicating the presence of large amounts of substances that are proteinic in nature (Fig. 13).

Observations of SY (E110) - treated group were encountered severe collapse in proteinic picture of the seminiferous tubules, as marked in figure 14 . The most remarkable lesion observed in this respect included reduced tubular dimensions (tubular atrophy), loss of all tubular elements and hyalinization forming degenerated vacuoles in most the seminiferous tubules (Fig. 14). Such vacuoles had seen in the seminiferous tubules taking either clear hyaline vacuole, whereas in such sections the distinct signs of diminution of the total proteins were observed in all spermatogenic and Sertoli cells, being suffering from a vacuolar degeneration and reflecting halo of remaining proteinic contents lining the cell membranes. Moreover, the acrosomic system in both the late spermatids and sperms displayed a similar decrease in protein affinity. Such phenomenon of vacuolation was also detected in the interstitial cells (Fig. 14). The inspection the specimens administered the equivalent ADI dose of E100 (i.e., 0.37 $\mathrm{mg} / \mathrm{kg}$ b.wt.) of curcumin for 60 days reflected that their seminiferous tubules were still attaining their control configuration and frequent all spermatogenic cells (Fig. 15).

\section{3-3-Sperm parameters}

To evaluate the effect of SY (E110) and CU (E100) on sperm quality; the sperm morphology involving the abnormalities in either sperm state of acrosome (Fig. 16 \& Fig. 17; b-d and g-h) or tails (Fig 17; b-e), and sperm viability were investigated, as manifested in Table 1 . It was shown that SY induced a decrease in sperm quality in comparison with their controls. In this group we detected an elevation in the number of morphological abnormal spermatozoa in statistically highly significant increase $(P<0.0001)$ after feeding of male mice on E110 (SY) for 60 days (Table 1). However, the treatment of $\mathrm{Cu}$ (E100) for the same period did not generate such influences on morphology of sperm, but inversely it caused a little improvement, recording insignificant decrease of sperm abnormalities in confrontation with SY (E110) to their control ones, as evidenced by table 1 and figure 17. Another sperm parameter studied in this investigation was represented by sperm motility (Table 1). In this concern, the sperm motility was carried out a highly significant decrease $(P<0.0001)$ after exposure to E110 on viability of sperm in samples obtained from this group (Table 1). Although the food flavor E100 scored a relative improvement but in non-significant effect $(P>0.05)$ on the sperm motility comparable to control means.

\section{3-4-Measurement of Testosterone}

The oral feeding with $30 \mathrm{mg} / \mathrm{kg}$ b.wt./day of sunset yellow (E110) for 60 days caused a significant decrease $(P<0.05)$ in testosterone level in serum compared to the control group after application of the analysis of testosterone rat/mouse ELISA (Fig. 18). However, the study recorded a relative increase of the testosterone secretion in the sera of curcumin (E100)-feeding mice, but this increasing is not up to a statistically significant elevation $(P>0.05)$ compared to control group, as noted in figure 18 .

\section{3-5- Molecular Results}

In the present results, the RAPD-PCR patterns, dissimilarity coefficient and band commonality percentages, were estimated for figure 19.

The testicular genomic DNAs of mice have fed orally with equivalent ADI (Acceptable Daily Intake) dosage of 30 or $37 \mathrm{mg}$ of E110 or E100 / kg b.wt./ daily for interval 60 days, respectively, were subjected to fingerprinting amplification using the selected primer OPC07. Examination of characteristic patterns of RAPD-PCR between the control sample and two food colourants displaying that the total number of fragments of RAPDPCR patterns generated by using primer OPC07 were 7 bands in the control (3 DNA bands, estimating 1400, 1100 and $900 \mathrm{bp}$ ) and the treated group of SY (E110) forming just one band (900 bp), whereas the other two bands, which characteristic to control sample, are replaced with fragmented DNA as a diffused smear ranged from $(\sim 1400$ to $\sim 900 \mathrm{bp}$ ) with a markedly disappearance of the other two bands (1400\&1100bp). However, the administration of CU 


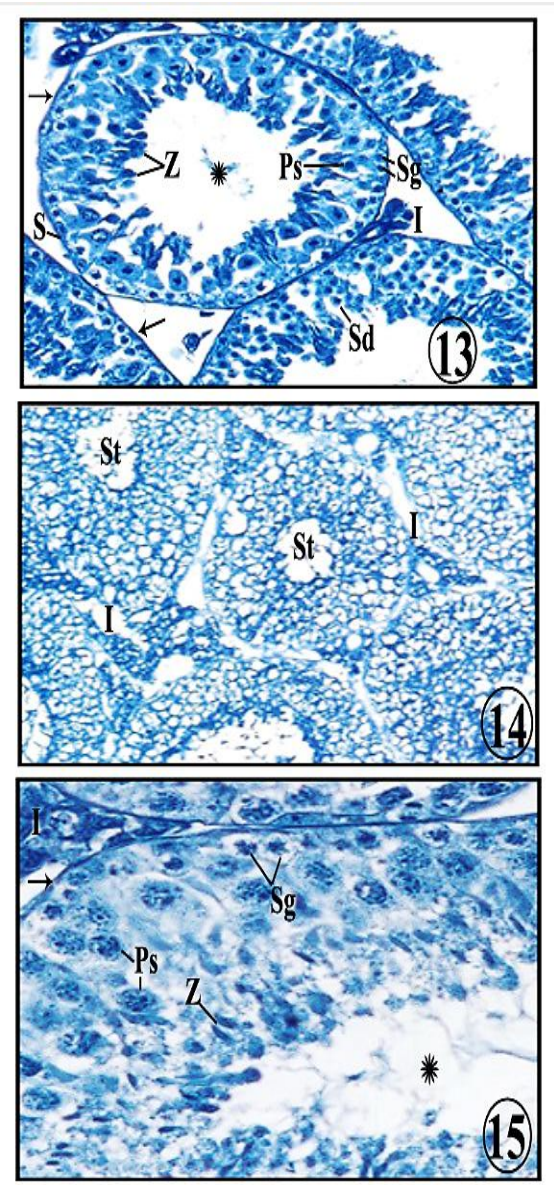

Fig. 13: A seminiferous tubule of a control mouse showing a normal distribution of the strongly stained total proteins in the germinal epithelial cells and the boundary tissue (arrows), spermatogonia (Sg), and interstitial tissue (I). The acrosomic system $(\mathrm{Z})$ in both late spermatids (Sd) and spermatozoa with their residual bodies are stained with deeply bluish colouration, surrounding the lumina (*). (mercury bromophenol blue X400)

Fig. 14: Testis section of SY-group, revealing vacuolar degeneration in both cytoplasmic and nuclear proteinic contents lining the nuclear and cell membranes of all spermatogenic and Sertoli cells with a marked inhibition of protein stain affinity. (X400)

Fig. 15: A magnified portion of a seminiferous tubule of a CU-group, indicating the normal distribution of total proteins in the germinal epithelium, as described in the above control specimen. (X650)

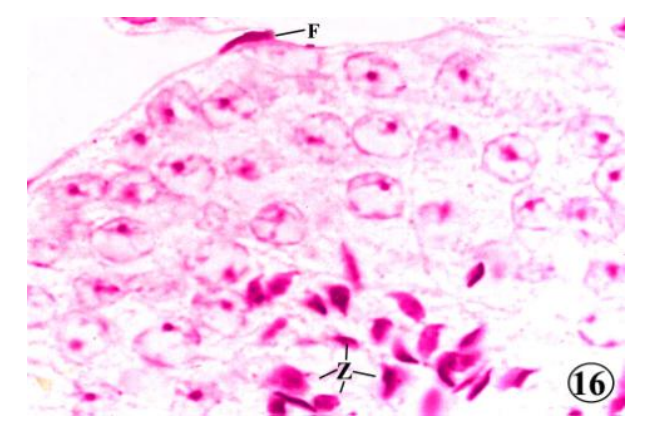

Fig. 16: A magnified sector of the testis treated with E110 (SY-group) and stained with Feulgen procedure, exhibiting marked abnormalities in the nuclei of acrosomic sperm states having strongly magenta staining (Z). The nuclei of spermatogenic epithelia appear suffering from apoptosis, besides the section contains well prominent fibrocyte nucleus (F). (X650) 

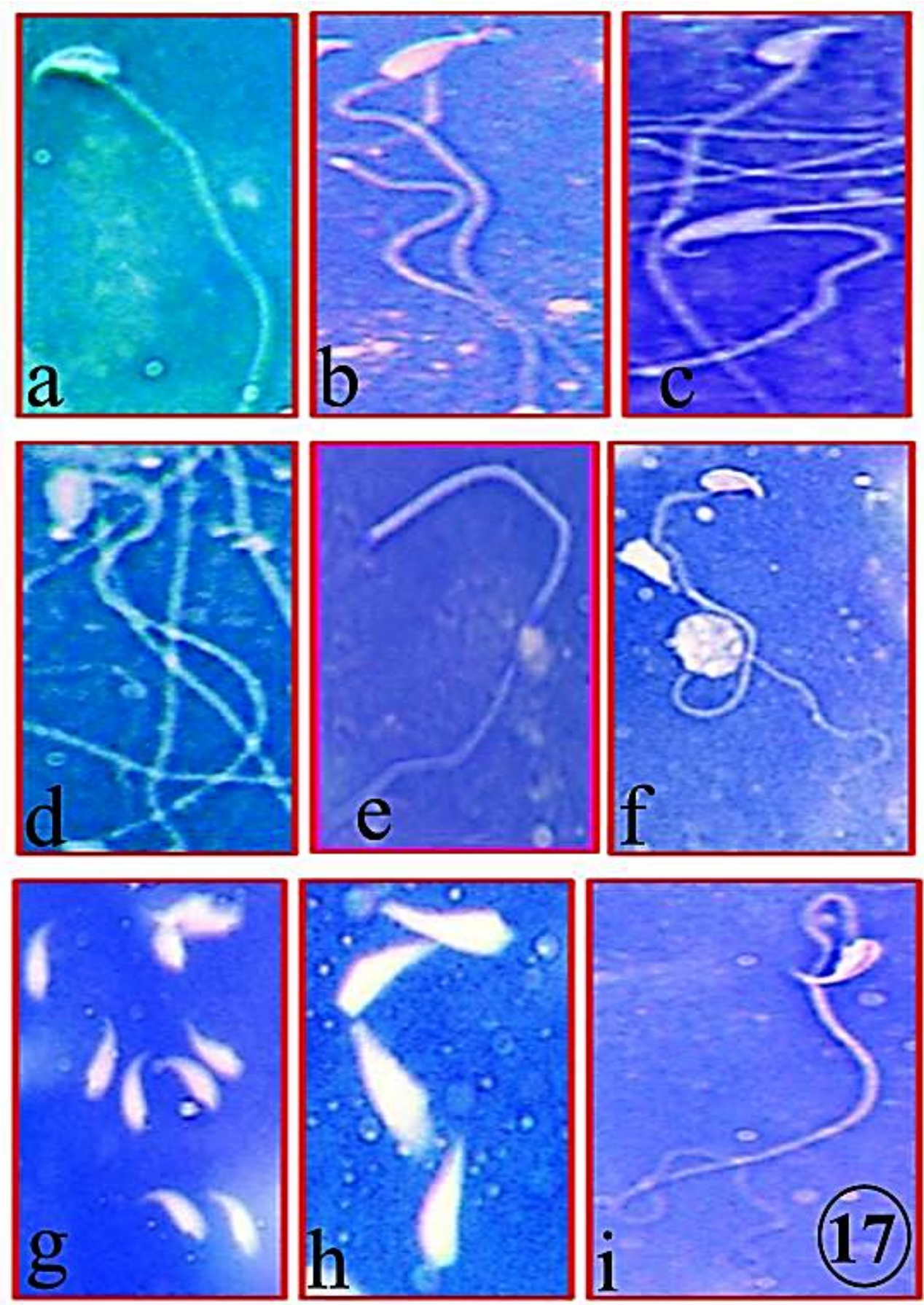

Fig 17: Photomicrographs Showing various numbers of morphological abnormal spermatozoa detected in mice after oral feed with equivalent ADI E110 (SY-group) including: various shapes of double-tailed sperm (b, c \& d) with a serrated-pointed acrosome (b) a drawn tapered tip (c) or hammered head sperm (d); acephalous sperm (e), sperm fusion with spermatid (f), tailless configuration (g), macrocephalous sperm (h) and hairpin loop sperm tail (i). The normal shape of mouse sperm obtained from control specimen is illustrated in figure (a). (X1000) 
Table 1: Means and Std. Deviation $( \pm \mathrm{SD}){ }^{\mathrm{n}=5}$ of sperm parameters (abnormalities of sperm morphology and sperm motility) of male mice oral fed with the equivalent ADI dose of either $30 \mathrm{mg} / \mathrm{kg}$ b.wt. of sunset yellow-E110 (SY-group) or with $37 \mathrm{mg} / \mathrm{kg}$ b.wt. of curcumin-E100 (CU-group) daily for 60 days, and their respective control group.

\begin{tabular}{|c|c|c|c|c|c|c|c|c|c|}
\hline \multirow{3}{*}{$\begin{array}{l}\text { Experimental } \\
\text { Animal } \\
\text { Groups }\end{array}$} & \multirow{3}{*}{$\begin{array}{l}1000 \\
\text { Sperm/ } \\
5 \text { Mice } \\
\text { (200/ } \\
\text { Mouse) }\end{array}$} & \multicolumn{8}{|c|}{ Sperm Parameters } \\
\hline & & \multicolumn{4}{|c|}{$\begin{array}{l}\text { Sperm Abnormalities } \\
\text { (Heads \& Tails) }\end{array}$} & \multicolumn{4}{|c|}{ Sperm Motility } \\
\hline & & $\begin{array}{l}\text { No/ } \\
200 \\
\text { Sperm }\end{array}$ & Mean & $\begin{array}{l}P \text { - } \\
\text { values }\end{array}$ & \pm SD & $\begin{array}{l}\text { No/ } \\
200 \\
\text { Sperm }\end{array}$ & Mean & $\begin{array}{l}P \text { - } \\
\text { values }\end{array}$ & \pm SD \\
\hline \multirow{5}{*}{$\begin{array}{l}\text { Control- } \\
\text { Group }\end{array}$} & Mouse01 & 30 & \multirow{5}{*}{23.6} & \multirow{5}{*}{-} & \multirow{5}{*}{ \pm 4.560} & 112 & \multirow{5}{*}{124.6} & & \multirow{5}{*}{ \pm 11.458} \\
\hline & \begin{tabular}{|l|} 
Mouse02 \\
\end{tabular} & 26 & & & & 117 & & & \\
\hline & Mouse03 & 22 & & & & 134 & & & \\
\hline & Mouse04 & 22 & & & & 121 & & & \\
\hline & Mouse05 & 18 & & & & 139 & & & \\
\hline \multirow{5}{*}{$\begin{array}{l}\text { SY-Group } \\
\text { (feed on } \\
\text { E110) }\end{array}$} & Mouse01 & 86 & \multirow{5}{*}{94} & \multirow{5}{*}{$P^{* *} \uparrow$} & \multirow{5}{*}{ \pm 11.661} & 47 & \multirow{5}{*}{51.8} & \multirow{5}{*}{$\boldsymbol{P}^{* *} \downarrow$} & \multirow{5}{*}{ \pm 9.230} \\
\hline & \begin{tabular}{|l|} 
Mouse02 \\
\end{tabular} & 102 & & & & 53 & & & \\
\hline & \begin{tabular}{|l|} 
Mouse03 \\
\end{tabular} & 106 & & & & 39 & & & \\
\hline & \begin{tabular}{|l|} 
Mouse04 \\
\end{tabular} & 98 & & & & 57 & & & \\
\hline & Mouse05 & 78 & & & & 63 & & & \\
\hline \multirow{5}{*}{$\begin{array}{l}\text { CU- Group } \\
\text { (feed on } \\
\text { E100) }\end{array}$} & Mouse01 & 24 & \multirow{5}{*}{22.8} & \multirow{5}{*}{$\boldsymbol{P} \downarrow$} & \multirow{5}{*}{ \pm 7.014} & 119 & \multirow{5}{*}{126.8} & \multirow{5}{*}{$\boldsymbol{P} \uparrow$} & \multirow{5}{*}{11.458} \\
\hline & \begin{tabular}{|l|} 
Mouse02 \\
\end{tabular} & 32 & & & & 122 & & & \\
\hline & Mouse03 & 18 & & & & 136 & & & \\
\hline & \begin{tabular}{|l|} 
Mouse04 \\
\end{tabular} & 26 & & & & 129 & & & \\
\hline & \begin{tabular}{|l|} 
Mouse05 \\
\end{tabular} & 14 & & & & 128 & & & \\
\hline
\end{tabular}

Level of significance:

$P>0.05$ is a statistically non-significant.

$* P<0.05$ is a statistically significant.

$* * P<0.0001$ is a statistically highly significant.

$\uparrow$ represents a significant increase.

$\downarrow$ represents a significant decrease.

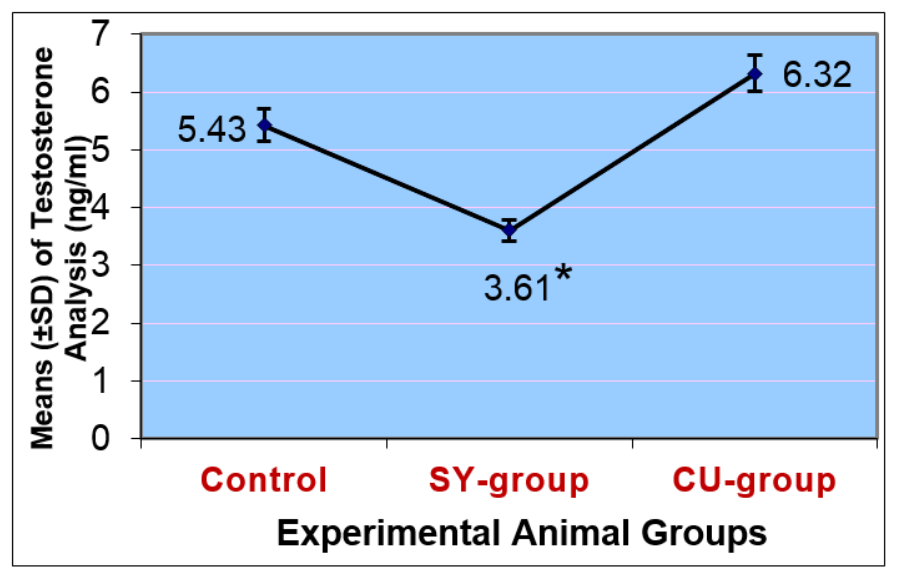

Fig. 18: Effect of E110 (SY-group) ${ }^{\mathrm{n}=6}$ and E100 (CU-group) ${ }^{\mathrm{n}=6}$ on testosterone levels in the sera of male mice indicates the significant differences among these groups. The chart showing a significant decrease $\left(\downarrow^{*} P<0.05\right)$ in testosterone concentration after treatment with E110, and a non-significant increase $(\uparrow P>0.05)$ in the treatment with a food colourant E100. 


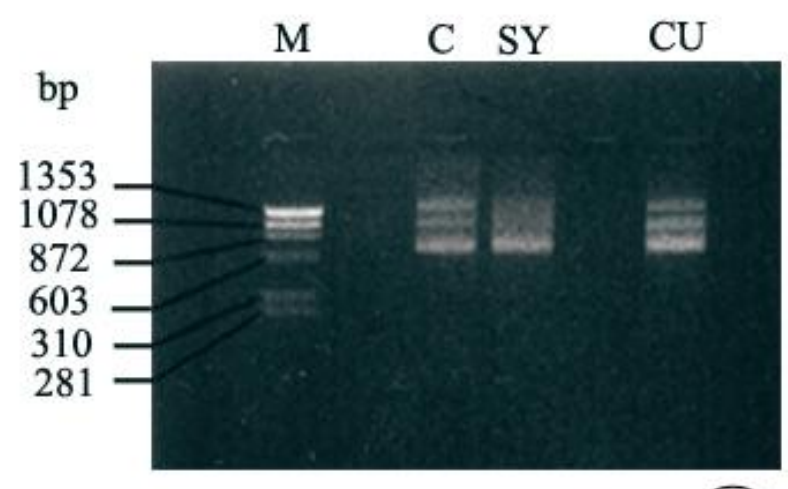

(19)

Fig. 19: Representative RAPD-PCR fingerprints generated from genomic DNA during SY (E110)- and CU (E100)-induced DNA polymorphic changes by primer OPC07, and their control pattern. Lane M: represents the DNA molecular size marker of $\varphi$ X174 DNA-HaeIII.

(E100) manifested three bands similar to the recorded in control sample, as evidenced by figure 19. According to the Jaccard's similarity Coefficient $(J)$ between the two treatments used in this investigation (sunset yellow; E110and curcumin; E100), the study recorded that the commonality \% of E100 (33\%) is more than E110 (20\%) in comparable to their control. However, the Jaccard's dissimilarity coefficient scored between E110 (80\%) more than E100 (67\%) compared to their control.

\section{Discussion}

Studies on the effect of SY (E110) on the testis and sperm parameters are limited. This is the starting point to select and assessment of such commonly used food coluorants in Egypt, particularly SY as a synthetic azo dye add to food and drug industries (Morrison, et al., 2012). So, the aim of this study was to describe the influences of SY and $\mathrm{CU}$ on the reproductive parameters in mice involving the histopathology, and DNA and total protein cytochemically of the testis, sperm quality by scoring their abnormalities and motility, measuring the testosterone in the sera, and fingerprinting polymorphism by applying the primer OPC07. This selected primer contains the sequencing of exons in tumorigenic cells, as investigated by (Zhou et al., 2013). Therefore, such criteria applied in this work on testis toxicity in mice may be evoke the decision to discriminate between the two food flavours 'E100 and E110' basing on each of them is more influencer than the other using the selected parameters. The observations obtained from the present light microscopic studies clearly demonstrated that the administration of SY to adult male mice induced various histopathological and cytochemical alterations in testicular tissues. Besides, the deteriorated impacts on sperm parameters and genomic DNA by oral feeding on equivalent ADI dosage of SY (30 mg/kg b.wt/daily for 60 days) to mice. On contrary, the treatment of equivalent ADI dosage of CU (37 mg/kg b.wt/daily for 60 days) performed little improvement in a nonsignificant statistical difference $(p \geq 0.05)$ in the selected parameters in this study. From the most histopathological implications progressed by SY on the testis obtained in this study included some seminiferous tubules showed exfoliated to their basement membranes and the lumens of others tubules occupying with sloughing of cells, mostly in early stages of spermatids and few malformed spermatozoa. In addition to disorganization of the germ cells and maturation arrest of various stages of spermatogenesis, besides necrosis of most germ cells in the affected tubules, such as karyorrhexis and pyknosis. In this concern, Seal (1988) documented that injuries in the male reproductive cells may be due to the lysosomal membranes by certain toxic agent lead to the release of certain hydrolytic enzymes such as Bglucuronidase and acid phosphatase from the injured lysosomes into the cytoplasm leading to necrosis or cell death. the cytoplasmic vacuolation may attributed to disturbance of ionic milieu of the cell with consequent retention of water and sodium leading to cellular swelling (Jaarsma et al., 2001 and Wiedemann et al., 2002), thereupon the accumulation of ions and fluids in cytosol would rapidly pass through leaky membranes of cell vacuolated organelles and finally lead to cell lysis (Gores et al., 1990, Sarhan and Al-Sahhaf, 2011). Also, Straus (1964) interpreted such vacuolation as pathological changes of permeability, whereas phagosomes and lysosomes lost their normal location and fused to form large vacuoles or spheres in kidney and liver of peroxidase-treated rats in an azo dye medium.

The present study detected also some lumens of seminiferous tubules contained the replacement of spermatogenic stages with multinucleate giant cells. In this respect, Matsuoka et al. (2001) found that azo dyes and their intermediates induced micronucleus and polynuclear cells, including binucleate cells and cells with a multilobed nucleus in two Chinese hamster cell lines, and condensed the chromatin in $100 \%$ of the cells with endoreduplication and chromosomal effects. The authors also reported that 
some of the azo chemicals induced a characteristic karyomorphology that might reflect abnormal cell division.

The testes weights in male mice after oral feeding with the equivalent ADI dose of either $30 \mathrm{mg}$ or $37 \mathrm{mg} / \mathrm{kg}$ b.wt./ daily, for 60 days in both SY- or CU-group respectively, and their related control group, recorded a significant decrease $(P<0.05)$ in the testis weight after treatment with E110 (SY-group), and a non-significant increase $(P>0.05)$ in the set of E100 (CU-group). These observations are reinforced by Sharma et al. (2008), who found the adverse effects of a commonly used dye blend, tomato red, on the vital organs of male Swiss albino mice. These effects recorded a decrease in the weights of testes, and the histopathological observations revealed severe degenerative changes in the testes.

To shedding light on the biological mechanisms responsible for sperm abnormalities were dealt with many studies. Wyrobek et al. (1975) stated that, in the mouse, the numerous mutagens, teratogens and carcinogens have been shown to induce marked elevations in the fraction of sperm with head shape abnormalities. Since carcinogens and teratogens may act by causing genetic damage. Reproductive difficulties are associated intimately with cytogenetic abnormalities. However, the frequency of chromosomally unbalanced spermatozoa in reciprocal translocations averages $50 \%$, is strongly dependent on the chromosomes involved in the individual translocation, and may be slightly increased as a result of a small interchromosomal effect (Shi and Martin, 2001). Concerning to the meiotic division, Ferguson et al. (2007) detected that the defects in early meiotic events are thought to play a critical role in male infertility, and Recombination between the sex chromosomes may be a useful indicator for identifying men at risk of producing chromosomally abnormal sperm. Kirkpatrick et al. (2008) found that the infertile men with normal karyotypes displayed more frequent increases in sperm aneuploidy, particularly involving the sex chromosomes, than infertile men who were carriers of chromosomal rearrangements. Also the results by Qiu et al. (2008) indicated that the spermatozoa from patients with idiopathic severe oligoasthenozoospermia (reduced sperm motility and low spermatozoon count) contain greater DNA fragmentation and chromosomal aneuploidy and may lead to male infertility. Zukerman et al. (1986) interpret that when a patient whose semen contained $30 \%$ of sperm with double heads and double tails at various stages of attachment due to abnormal meiosis. In recently, Alchinbayev et al. (2016) found that the development of pathospermia was characterized by genetic discontinuity, which manifests as DNA fragmentation and disjunction of chromosomes in meiosis with spermatogenesis. In addition, they recorded that the highest rate of numerical chromosome abnormalities (such as aneuploidies), caused the degeneration of spermatozoids. Such observations are also in agreement with Ismail and Sakr (2016), on the effect of sunset yellow on bone marrow chromosomes. They recorded two main types of chromosomal aberrations, namely: structural (such as deletions/and or fragments, and ring chromosomes) and numerical ones (mainly represented by polyploidy) in a significantly increase $(p<0.05)$, when encountered with control- and curcumin-treated mice. Moreover, Enciso et al. (2013) reported that during spermatogenesis, apoptosis (a process that involves active DNA degradation) acts to eliminate abnormal sperm. Failure to complete apoptosis may explain the coincident detection of aneuploidy and DNA fragmentation in some spermatozoa, and involved in the processing of defective sperm, causing the elevated sperm DNA fragmentation, which may indicate the presence of chromosomal abnormalities. In more depth, the results by Boyer et al. (2016) indicated that Mtor expression in Sertoli cells is required for the maintenance of spermatogenesis and the progression of germ cell development through the pachytene spermatocyte stage. In the testis, physiological roles for Mtor have been proposed in perinatal Sertoli cell proliferation and blood-testis barrier (BTB) remodeling during spermatogenesis.

Despite the several concerns for selecting the mouse as experimental animal in this investigation, particularly on the molecular aspect, may be due to that the mouse is still one of the best animals in which to model human cancer. Firstly, mice are as susceptible to cancer as humans (Rangarajan and Weinberg, 2003). Secondly, the mouse and human genomes are approximately 95\% identical, and mice have many structurally similar genes and genomic alterations that have been implicated in cancer (Maser et al., 2007; De Jong and Maina, 2010). Therefore, the use of immunodeficient mouse models provide a platform for finding novel therapies to treat human patients afflicted with prostate cancer (Kenneth et al., 2011). However, the molecular assessment as detected in testicular DNA fingerprints and generated by primer OPC07 (5'ATTCTGGTTT-3') showing damaged genomic regions in SY-induced testicular DNA, and the unchanged RAPDPCR amplified loci in CU-induced cells compared with passage-matched control cells. RAPD-PCR revealed genomic instability in SY-exposed germ cells affecting specific exons in the DNA of mouse genome, as detected in the sequence analysis of DNA segments amplified by primer OPC07, which manifested the mutation of exons in hMSH2, ERCC1, XRCC1, and hOGG1 in tumorigenic cells, as discovered by Zhou et al. (2013). The results of bioassays with mammals, it was shown to be that azo dye metabolites were mutagenic and even carcinogenic (Feng et al., 2012). Nevertheless, Kashanian et al. (2012) interpreted the mechanism binds between SY and DNA reaction. The reaction is exothermic and enthalpy favored, which are the evidences to indicate that van der Waals interactions and hydrogen bonding are the main running forces in the binding between them. Such SY and DNA reaction exhibited the highest level of comet DNA damage in human germ cells exposed to the some food additives in vitro and followed by tail length and tail moment sperm alterations, indicating that SY is the more harmful on human sperm in vitro than the other applied food flavours (Pandir, 2014). Curcumin 'CU' (diferuloyl methane), the yellow-colored dietary pigment from the rhizomes of 
turmeric, has been recognized as a chemopreventive agent because of its antitumor, antioxidant and antiproliferative effects (Ramachandran et al., 2005). Furthermore, the findings by Motaghinejad et al. (2015) have demonstrated that curcumin can act as an antioxidant and antiapoptotic agent against DNA damage in rats. This may be interpret the reasons about the ameliorated selected protocols in the current study at the designed dosage (ADI) on the testis of mouse.

In conclusion, the present study explored the possibility of using the applied six parameters to assessment and differentiate between the two foods flavours, indicating that E100 (CU) is more biosafe as a natural colourant on the reproductive criteria in mouse, so it may be add to foodstuffs and drugs than the synthetic additive E110 (SY).

\section{References}

Abbey J., Fields B., O`Mullane M., Tomaska L.D. (2014). Food Additives: Colorants Encyclopedia of Food Safety; 2: 459-465.

Abou EL-Zahab H.S., El-Khyat Z.A., Awadalla R., Mahdy K.A. (1997). Physiological effects of some synthetic food coloring additives on rats. Boll. Chin. Farm, 136 (10): 615-627.

Alchinbayev M.K., Aralbayeva A.N., Tuleyeva L.N., Duysenbayeva S.M., Makazhanov M.A. (2016). Aneuploidies level in sperm nuclei in patients with infertility. Mutagenesis, Jun 6. pii: gew020.

Andrade F.I., Guedes M.I., Vieira I.G., Mendes F.N., Rodrigues P.A., Maia C.S., Avila M.M., de Matos Ribeiro $L$ (2014). Determination of synthetic food dyes in commercial soft drinks by TLC and ion-pair HPLC Food Chem., 157 (15): 193-198.

Ausubel, F. M.; Brent, R.; Kingston, R. E.; Moore, D. D.; Seidman, J. G.; Smith, J. A. and Struhl, K. (1989). Short protocols in molecular biology. Green Publishing Associates \& Wiley - Interscience, Canada, pp. 136 - 137.

Bancroft J.D., Gamble M. (2002). Theory and Practice of Histological Techniques. $5^{\text {th }}$. ed. Edinburgh. Churchill Livingstone Pub., pp 172-175.

Botelho B.G., de Assis L.P., Sena M.M. (2014). Development and analytical validation of a simple multivariate calibration method using digital scanner images for sunset yellow determination in soft beverages. Food Chem., 159 (15): 175-180.

Boyer A., Girard M., Thimmahahalli D.S., Levasseur A., Céleste C., Paquet M., Duggavathi R., Boerboom D. (2016). mTOR Regulates gap junction alpha-1 protein trafficking in Sertoli cells and is required for the maintenance of spermatogenesis in mice. Biol. Reprod., 115.138016.

Chan M.M. (1995). Inhibition of tumor necrosis factor by curcumin, a phytochemical. Biochemical. Pharmacol., 49: 1551-1556.

Cheng A.L., Hsu C.H., Lin J.K. (2001). Phase I clinical trial of curcumin, a chemopreventive agent, in patients with high-risk or pre-malignant lesions. Anticancer Res., 21: 2895-2900.
Collard B.C.Y., Mackill D.J. Start codon targeted (SCoT) polymorphism: a simple, novel DNA marker technique for generating gene targeted markers in plants (2009). Plant Mol. Biol. Rep., 27:86-93.

Darlington C. D., Cour L. F. (1969): The handling of chromosomes. George Allen \& Unwin. Ltd., London. pp. 163 - 166. (Quoted from Kasten, F.H., 2003).

De Jong M., Maina T. (2010). "Of mice and humans: are they the same?- implications in cancer translational research," Journal of Nuclear Medicine, 51 (4): 501-504.

Duvoix A., Blasius R., Delhalle S., Schnekenburger M., Morceau F., Henry E., Dicato M., Diederich M. (2005). Chemopreventive and therapeutic effects of curcumin. Cancer Letters, 223 (2): 181-190.

EFSA (European Food Safety Authority), Parma, Italy (2010). Scientific opinion on the re-evaluation of curcumin (E100) as a food additive. EFSA Panel on Food Additives and Nutrient Sources added to Food. EFSA J., 8 (9): 1679- 1725.

Eigner D., Sholz D. (1999). Ferula asa-foetida and curcuma longa in traditional medical treatment and diet in Nepal. J. Ethnopharmacol, 67: 1-6.

Enciso M., Alfarawati S., Wells D. (2013). Increased numbers of DNA-damaged spermatozoa in samples presenting an elevated rate of numerical chromosome abnormalities. Hum. Reprod., 28 (6):17071715.

Feng, J., Cerniglia C.E., Chen H. (2012). Toxicological significance of azo dye metabolism by human intestinal microbiota. Frontiers in Bioscience (Elite Edition), 1 (4): 5680-5686.

Ferdowsian H.R., Beck N. (2011). Ethical and Scientific Considerations Regarding Animal Testing and Research. PLoS One, 6 (9):e24059.

Ferguson K.A., Wong E.C., Chow V., Nigro M., Ma S. (2007). Abnormal meiotic recombination in infertile men and its association with sperm aneuploidy. Hum. Mol. Genet., 16(23):2870-2879.

Franceschi F., Togni S., Appendino G. (2015). Curcumin and neurological/brain disorders. In: Bioactive nutraceuticals and dietary supplements in neurological and brain disease, prevention and therapy. Chapter 21, 1st Ed. and Edited by: Watson R.R. and V.R. Preedy. Academic Press, elsevierdirect.com. Pp: 197-204.

Gomes K.M.S., Oliveira M.V.G., Carvalho F.R., Menezes C.C., Peron A.P. (2013). Cytotoxicity of food dyes sunset yellow (E-110), bordeaux red (E-123), and tartrazine yellow (E-102) on Allium cepa L. root meristematic cells. Food Sci. Technol. (Campinas), 33 (1), On-line version ISSN 1678-457X.

Gores, G.J., Herman B., Lemasters J.J. (1990). Plasma membrane bleb formation and rupture: a common feature of hepatocellular injury. Hepatology, 11(4): 690698.

Hajimahmoodi M., Afsharimanesh M., Moghaddam G., Sadeghi N., Oveisi M.R., Jannat B., Pirhadi E., Zamani Mazdeh F., Kanan H. (2013). Determination of eight synthetic dyes in foodstuffs by green liquid 
chromatography. Food Addit. Contam. Part A Chem. Anal. Control Expo. Risk Assess., 30 (5): 780-785.

Ha M.S., Ha S.D., Choi S.H., Bae D.H. (2013). Exposure assessment of synthetic colours approved in Korea. Food Addit. Contam. Part A Chem. Anal. Control Expo. Risk Assess, 30 (4): 643-653.

Harris J.B. (1986). Natural toxins. Animal, plant and microbial. In: Food and childhood. Boston: Blackwell scientific publication, pp 179.

Hashem M.M., Atta A.H., Attia H., Arbid M.S., Nada S.A., Mouneir S.M., Asaad G.F. (2011). Toxicological impact of amaranth, sunset yellow and curcumin as food colouring agents in albino rats. JPMS, 1 (2): 43-51.

Ismail M.A.; Sakr S.M. (2016). Validation of replacement of the synthetic food dye "sunset yellow"induced hepatotoxicity and genotoxicity with the nutraceutical "curcumin" in mice. Merit Res. J. Med. Med. Sci., 4 (1): 025-050.

Jaarsma D., Rognoni F., van Duijn W., Verspaget H.W., Haasdijk E.D., Holstege J.C. (2001). CuZn superoxide dismutase (SOD1) accumulates in vacuolated mitochondria in transgenic mice expressing amyotrophic lateral sclerosis-linked SOD1 mutations. Acta Neuropathol., 102 (4): 293-305.

JECFA. $26^{\text {th }}$. Report of the Joint FAO/WHO Expert Committee on Food Additives. (1982). Toxicological evaluation of certain food additives. WHO Food Additives Series, No. 17.

JECFA (Joint FAO/WHO Expert Committee on Food Additives) (2004). Evaluation of certain food additives and contaminants. Sixty-first report of the Joint FAO/WHO Expert Committee on Food Additives. WHO Technical Report Series 922. Geneva. Available at: http://whqlibdoc.who.int/trs/WHO_TRS_922.pdf.

Jordan W.C., Drew C.R. (1996). Curcumin - a natural herb with anti- HIV activity. Natl. Med. Assoc., 88: 333.

Jungnickel M.K., Marrero H., Birnbaumer L., Lémos J. \& Florman H. M. (2001). Trp2 regulates entry of Ca2+ into mouse sperm triggered by egg ZP3. Nature Cell Biology, 3: 499-502.

Kashanian S., Zeidali S.H., Omidfar K., Shahabadi N. (2012). Multi-spectroscopic DNA interaction studies of sunset yellow food additive. Molecular Biology Reports, 39(12): 10045-10051.

Kasten F.H. (2003): Robert Feulgen and his histochemical reaction for DNA. Biotechnic \& Histochemistry, 78(1): 45-49. Feulgen R., Rossenbeck H. (1924): Z. phsiol. Chem., 135: 303.

Kenneth C. Valkenburg K. C., Bart O. Williams B.O. (2011). Mouse Models of Prostate Cancer. Prostate Cancer, vol. 2011, Article ID 895238, 22 pages. doi:10.1155/2011/895238

Kirkpatrick G., Ferguson K.A., Gao H., Tang S., Chow V., Yuen B.H., Ma S. (2008). A comparison of sperm aneuploidy rates between infertile men with normal and abnormal karyotypes. Hum. Reprod., 23 (7):16791683.
Kumar K.N., Maruthi K.R., Alfarhan A.H., Rajakrishnan R., Thomas J. (2016). Molecular fingerprinting of Helicanthus elastica (Desr.) Danser growing on five different hosts by RAPD. Saudi J.Biological Sciences, 23 (3): 335-340.

Li W.J., Zhou X., Tong S.S., Jia Q. (2013). Poly (Nisopropylacrylamide-co-N,N`-methylene bisacrylamide) monolithic column embedded with $\gamma$-alumina nanoparticles microextraction coupled with high-performance liquid chromatography for the determination of synthetic food dyes in soft drink samples. Talanta, 105: 386-392.

Maniatis, T., Fritsch, E. F., Sambrook, J. (1982). Molecular cloning: A laboratory manual. Cold Spring Harbor Laboratory Press, New York.

Mariadason J.M., Corner G.A., Augenlicht L.H.(2000). Genetic reprogramming in pathways of colonic cell maturation induced by short chain fatty acids: comparison with trichostatin a, sulindac, and curcumin and implications for chemoprevention of colon cancer. Cancer. Res., 60: 4561-4572.

Maser R.S., Choudhury B., Campbell P. J., et al. (2007). "Chromosomally unstable mouse tumours have genomic alterations similar to diverse human cancers. Nature, 447 (7147): 966-971.

Masuda T., Hidaka K., Shinohara A., Maekawa T., Takeda .Y, Yamaguchi H.J. (1999). Chemical studies on antioxidant mechanism of curcuminoid: analysis of radical reaction products from curcumin. Agric. Food Chem., 47: 71-77.

Matsuoka A, Tada A, Terao Y, Nukaya H, Onfelt A, Wakabayashi K (2001). Chromosomal effects of newly identified water pollutants PBTA-1 and PBTA-2 and their possible mother compounds (azo dyes) and intermediates (non-ClPBTAs) in two Chinese hamster cell lines. Mutat. Res., 493 (1-2): 75-85.

Mazia, D.; Brewer, A. P. and Alfert, M. (1953): The cytochemical staining and measurement of protein with mercuric bromophenol blue. Biol. Bull., 104: 57.

Morrison, J.M., Wright C.M., John G.H. (2012). Identification, isolation and characterization of a novel azoreductase from Clostridium perfringens. Anaerobe, 18 (2): 229-234.

Motaghinejad M, Karimian M, Motaghinejad O, Shabab B, Yazdani I, Fatima S (2015). Protective effects of various dosage of Curcumin against morphine induced apoptosis and oxidative stress in rat isolated hippocampus. Pharmacological Reports, 67 (2): 230-235.

Nagabhushan M., Amonkar A.J., Bhide S.V. (1987). In vitro antimutagenicity of curcumin against environmental mutagens. Food Chem. Toxicol., 25: 545547.

NTP (National Toxicology Program) (1981). Carcinogenesis Bioassay of FD \& amp; C Yellow No. 6 (CAS No. 2783-94-0), Natl. Toxicol. Program Tech. Rep. Ser., Volume 208, PMID: 12778227.

Pandir D. (2014). DNA damage in human germ cell exposed to the some food additives in vitro. Cytotechnology, pp. 1-9. DOI 10.1007/s10616-014-9824-y. 
Pari L., Tewas D., Eckel J. (2008). Role of curcumin in health and disease. Arch. Physiol. Biochem., 114: 12749.

Qiu Y., Wang L., Zhang L., Yang D., Zhang A., Yu $\mathrm{J}$. (2008).

Analysis

of sperm chromosomal abnormalities and sperm DNA fragmentation in infertile males. Zhonghua Yi Xue Yi Chuan Xue Za Zhi., 25(6):681-685.

Rajamanickam D., Dhatshanamurthi P., Shanthi M. (2015). Preparation and characterization of SeO2/TiO2 composite photocatalyst with excellent performance for sunset yellow azo dye degradation under natural sunlight illumination. Spectrochimica Acta Part A: Molecular and Biomolecular Spectroscopy, 138: 489-498.

Ramachandran C, Rodriguez S, Ramachandran R, Raveendran PK, Fonseca H, Khatib Z, Escalon E, Melnick SJ (2005). Expression profiles of apoptotic genes induced by curcumin in human breast cancer and mammary epithelial cell lines. Anticancer Res., 25 (5): 3293-3302.

Rangarajan A. and Weinberg R. A. (2003). Comparative biology of mouse versus human cells: modelling human cancer in mice. Nature Reviews Cancer, vol. 3 (12): 952-959.

Rao T.S., Basu N., Siddigui H.H. (1982). Antiinflammatory activity of curcumin analogues. Indian $\mathrm{J}$. Med. Res., 75: 574-578.

Reagan-Shaw S., Nihal M., Ahmad N. (2008). Dose translation from animal to human studies revisited. FASEB J., 22 (3): 659-661.

Sarhan O.M.M., Al-Sahhaf Z.Y. (2011). Histological and biochemical effects of diazinon on liver and kidney of rabbits. Life Science Journal, 8 (4):1183-1189.

Satoskar R.R., Shah S.J., Shenoy S.G. (1986). Evaluation of anti-inflammatory property of curcumin (diferuloyl methane) in patients with postoperative inflammation. Int. J. Clin. Pharmcol. Ther. Toxicol., 24: 651-654.

Sayed H.M., Fouad D., Ataya F.S., Hassan N.H., Fahmy M.A. (2012). The modifying effect of selenium and vitamins $A, C$ and $E$ on the genotoxicity induced by sunset yellow in male mice. Mutation Research, 744 (2): 145-153.

SCF (1984). Reports of the Scientific Committee for Food (14 ${ }^{\text {th }}$. Series), opinion expressed, 1984; 6.

Seal, R. (1988). Effect of parathion on the male reproductive system. Ind. J. Physiol. \& Allied Sci., 42(3): 102-112.

Sharma R.A., Euden S.A., Platton S.L. (2004). Phase I clinical trial of oral curcumin: biomarkers of systemic activity and compliance. Clin. Cancer Res., 10: 6847-6854.

Sharma S, Goyal R.P., Chakravarty G., Sharma A. (2008). Toxicity of tomato red, a popular food dye blend on male albino mice. Exp. Toxicol. Pathol., 60 (1): 51-57.

Shen Y., Zhang X., Prinyawiwatkul W., Xu Z. (2014). Simultaneous determination of red and yellow artificial food colourants and carotenoid pigments in food products. Food Chem., 157 (15): 553-558.

Shi Q., Martin R.H. (2001). Aneuploidy in human spermatozoa: FISH analysis in men with constitutional chromosomal abnormalities, and in infertile men. Reproduction, 121(5):655-666.

Singh S., Aggarwal B.B. (1995). Activation of transcription factor NFkappa B is suppressed by curcumin (diferuloylmethane). J. Biol. Chem., 270: 24995-25000.

Srivastava R, Puri V, Srimal RC, Dhawan BN (1986). Effect of curcumin on platelet aggregation and vascular prostacyclin synthesis. Arzneim. Forsch./Drug Res., 36: 715-717.

Straus W. (1964). Cytochemical observations on the relationship between lysosomes and phagosomes in kidney and liver by combined staining for acid phosphatase and intravenously injected horseradish peroxidase. J. Cell Biol., 20:497-507.

Takeda N., Yoshinaga K., Furushima K., Takamune K., Li Z., Abe S., Yamamura K. (2016). Viable offspring obtained from Prm1-deficient sperm in mice. Sci. Rep. 6, 27409.

Tripathi M., Khanna S.K., Das M. (2007). Surveillance on use of synthetic colours in eatables vis a vis Prevention of Food Adulteration Act of India. Food Control, 18 (3): 211-219.

Vasques E.C., Carpiné D., Dagostin J.L., Canteli A.M., Igarashi-Mafra L., Mafra M.R., Scheer A.P. (2014). Modelling studies by adsorption for the removal of sunset yellow azo dye present in effluent from a soft drink plant. Environ. Technol.; 35 (9-12): 1532-1540.

Wang M., Zhang J., GaoY., Yang X., Gao Y., Zhao J.(2014). Determination of Sunset Yellow in soft drinks at attapulgite modified expanded graphite paste electrode. J. Eelectrochem. Soc. 161 (3): H86-H91.

Wiedemann F.R., Manfredi G., Mawrin C., Beal M.F., Schon E.A. (2002). Mitochondrial DNA and respiratory chain function in spinal cords of ALS patients. J. Neurochem., 80 (4): 616-625.

Wu H., Guo J.B., Du L.M., Tian H., Hao C.X., Wang Z.F., Wang J.Y. (2013). A rapid shaking-based ionic liquid dispersive liquid phase microextraction for the simultaneous determination of six synthetic food colourants in soft drinks, sugar- and gelatin-based confectionery by high-performance liquid chromatography. Food Chem., 141 (1): 182-186.

Wyrobek A.J., Heddle J.A., Bruce W.R. (1975). Chromosomal abnormalities and the morphology of mouse sperm heads. Can. J. Genet. Cytol., 17(4):675-681.

Zhou Z., Wang C., Liu H., Huang Q., Wang M., Lei Y. (2013). Cadmium Induced Cell Apoptosis, DNA Damage, Decreased DNA Repair Capacity, and Genomic Instability during Malignant Transformation of Human Bronchial Epithelial Cells. Int. J. Med. Sci., 10(11):14851496.

Zukerman Z., Sagiv M., Ravid A., Ben-Bassat M., Malik Z., Shohat B., Tadir Y., Ovadia Y., Singer R. (1986). A high proportion of double-headed and doubletailed sperm in semen of a human male. A case report. Andrologia., 18(5):495-501. 